DOI: $10.1515 /$ pts-2016-0015

RADIO ASTRONOMY

\title{
THE INFLUENCE OF WIND TURBINES ON RADIO ASTRONOMICAL OBSERVATIONS IN IRBENE
}

\author{
D. Bezrukovs \\ Ventspils International Radio Astronomy Centre \\ 101 Inzenieru Str., Ventspils, LV-3601, LATVIA \\ dmitrijs.bezrukovs@venta.lv
}

\begin{abstract}
The reflection and diffraction of external communication and navigational transmitters from tall constructions and moving blades of wind turbines produce some short-pulse additional electromagnetic interference strong enough to fully disturb radio astronomical observations. The problem of shortpulse electromagnetic interference is distinctive to all radio telescopes surrounded by wind turbines. This problem became significant for Ventspils International Radio Astronomy Centre (VIRAC) after new wind park "Platene" of Winergy Ltd. was built in 2012 and radio telescopes RT-16 and RT-32 renovated and equipped with cryogenic high sensitive receivers. The paper deals with the analysis and evaluation of intensities and probabilities of short-pulse interferences produced by wind park "Platene" and its possible impact on radio astronomical observations at VIRAC radio telescopes.
\end{abstract}

Keywords: electromagnetic interferences, radio astronomy.

\section{INTRODUCTION}

Obviously the utilisation of wind power for electricity generation is the growing issue for power generation with a minimal environmental impact. Due to external pressure of "green" organisations, the common EU policy and EU regulations, commercial structures and others, a number of wind power installations are increasing dramatically everywhere. Sometimes the real impact of new wind installations on the local environment appears to be rather unpredictable.

One of wind energy installation effects on a local environment is a possible influence on radio astronomical observations performed by closely located radio telescopes. Tall towers and blades of wind turbines located in the close zones of big radio telescope antennas disturb the uniformity of the electromagnetic environment and produce some additive passive electromagnetic interference. Due to the reflection and scattering of the emission of close communication and navigation transmitters from wind turbine moving blades, periodical shot-pulse interference occurs. This sporadic short-pulse interference is able to fully disturb radio astronomy obser- 
vations performed by modern sensitive cryogenic receivers of radio telescopes. The problem mentioned is characteristic of most radio telescopes [2]-[6].

The interference produced by a number of reflected and diffracted side beams has a form of periodical sequences of short pulses with different lengths of milliseconds. In most cases, the interference is sporadic and unpredictable. This kind of interference has a wide and irregular spectrum. The detection and mitigation of similar interference are the most sophisticated task compared to the mitigation of permanent interference by known methods. Taking into account the significance of VLBI (Very Long Base Interferometry) observations, rather weak pulse interference at one of radio telescopes is able to fully violate the observation of the whole radio telescope network.

Along with the creation of wind park "Platene", the problem of pulse electromagnetic interference produced by moving blades of its wind turbines became significant and urgent to radio telescopes RT-32 and RT-16 of Ventspils International Radio Astronomy Centre (VIRAC). The present research is just the first attempt to analyse and evaluate some possible effects of wind park "Platene" on the quality of radio astronomical observations implemented by VIRAC RT-32 and RT-16.

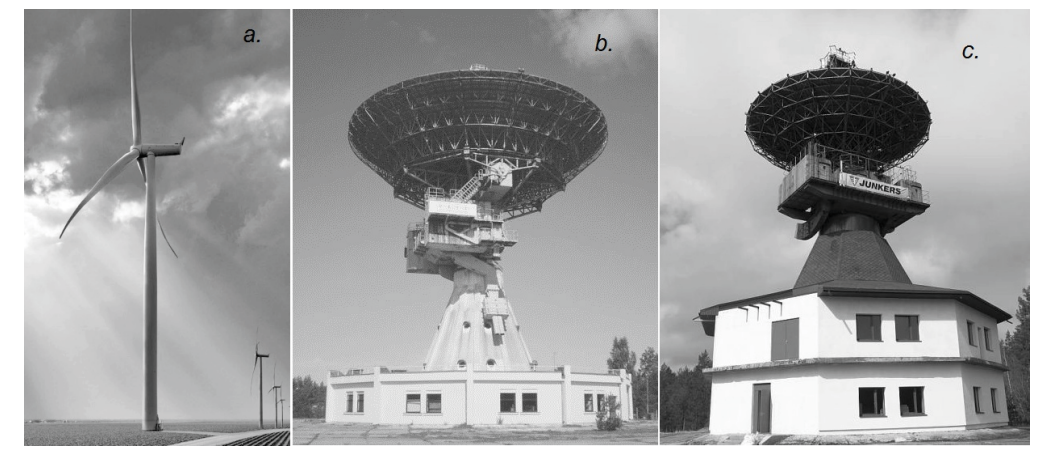

Fig. 1. Siemens SWT-2.3-101 wind turbine, (a) VIRAC radio telescopes RT-32 (b) and RT-16 (c).

\section{THE ELECTROMAGNETIC ENVIRONMENT OF VIRAC RADIO TELESCOPES}

Radio telescopes RT-16 and RT-32 (Fig. 1, b, c) are the main instruments of VIRAC. After considerable renovation in 2015, they are expected to be involved in a lot of observational programs. The earliest forms are VLBI (Very Large Base Interferometry) in EVN (European VLBI Network), interferometric radio location of space debris and satellites, solar spectral polarimetric observations. Radio telescopes are expected to be equipped with cryogenic radiometers for extended C-band (5 $\mathrm{GHz}$ ), frequency bands of $327 \mathrm{MHz}, 1.8 \mathrm{GHz}, 6.3-9.3 \mathrm{GHz}$ are also expected to be used.

Although radio telescopes are located in rather unpopulated site Irbene, they are actually surrounded by a number of various transmitters. Among them several GSM basic stations and digital television transmitters are directly visible and known. A number of maritime and border guard communication, navigation and radio location transmitters are also located in Ventspils and along the sea cost. 
In 2012 the wind park "Platene" of Winergy Ltd. was built and started to work permanently. The wind park consists of 13 wind turbines located near Platene (two groups of 4 and 5 wind turbines) and Vede (the group of four wind turbines). The wind park is equipped with widely used SIEMENS SWT-2.3-101 wind turbines (Fig. 1, a). The distance from Irbene radio telescopes to Platene is $19.7 \mathrm{~km}$ and to Vede is $8.2 \mathrm{~km}$. Towers of wind turbines are about $100 \mathrm{~m}$ in height and turbine blade length is $39 \mathrm{~m}$. Thus, towers and turbines are in the direct visibility from focal centres of both radio telescope antennas above the surrounded forest. Obviously all wind turbines are located in the close zone of at least RT-32 antenna. The mutual location of GSM and digital television transmitters, groups of wind turbines and radio telescopes are shown in Fig. 2.

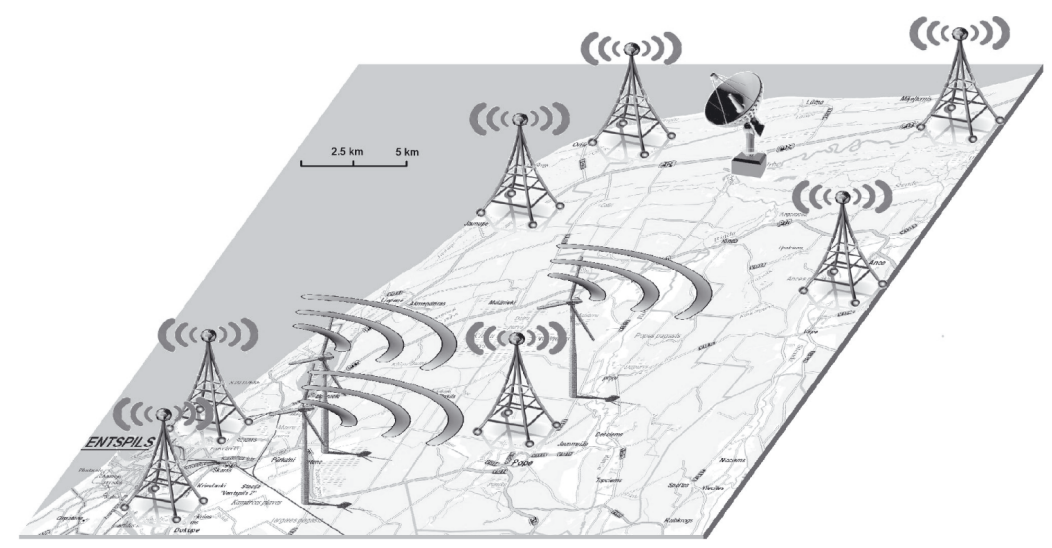

Fig. 2. The location of GSM/DTV towers, groups of wind turbines and VIRAC radio telescopes.

The monitoring of radio interference in Irbene has shown that there is main permanent interference at frequencies of digital television (DVB-T) and GMS mobile communication 900/1800 Mhz. The example of interference monitoring performed in 2014 is shown in Fig. 3. The interference intensity of all GSM transmitters is above the threshold level defined by recommendation [8] and strong enough to produce harmonic interferences in protected radio astronomical frequency bands and intermodulation distortions in the sensitive receiver and frequency conversion units.

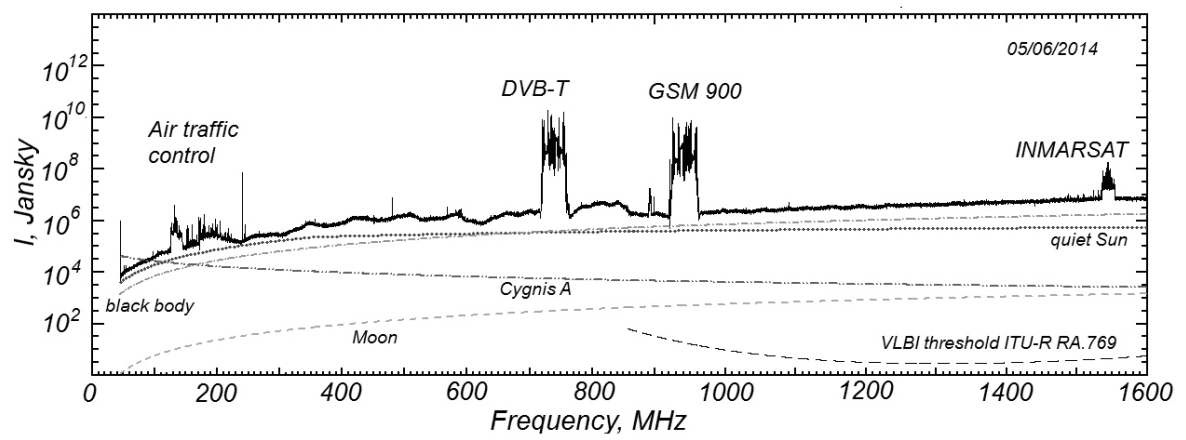

Fig. 3. The spectrum of the isotropic interference flux density in Jansky $\left(1 \mathrm{Ja}=10^{-26} \mathrm{Wm}^{-2} \mathrm{~Hz}^{-1}\right)$ measured at the secondary focus of RT-32 and its comparison with known radio astronomical sources and threshold limit by recommendation [7]. 
Radio interference in C-band and higher frequencies is sporadic and the source of it usually cannot be detected precisely. The example of similar sporadic short-pulse interference recorded during the spectral polarimetric observation of the Sun by RT-32 radio telescope is presented in Fig. 4. The interference of $9.3 \mathrm{GHz}$ has a rather narrow frequency band (about $80 \mathrm{MHz}$ - one channel of the 16 band spectral polarimeter for 6.3-9.3 GHz band). The intensity of pulses achieved the spectral flux density of quiet Sun. The source of interference was not detected. During this observation, the antenna azimuth of RT-32 was about 200 deg., so most likely one could explain it as reflection of some maritime radar from towers of "Platene" wind park.

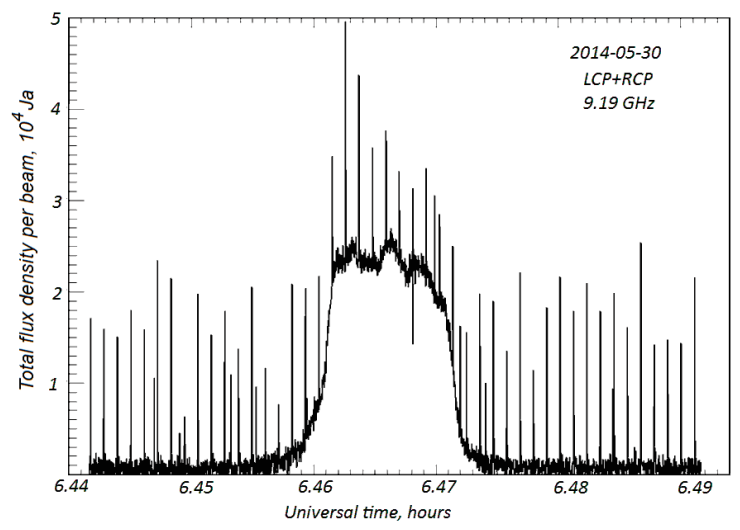

Fig. 4. The record of one Sun scanning by RT-32 during the spectral polarimetric solar observation affected by periodical pulse interference at $9.19 \mathrm{GHz}$.

\section{THE EVALUATION OF PROBABLE PULSE INTERFERENCE PRODUCED BY WIND TURBINES}

The precise estimation and prediction of pulse interference produced by wind turbines is a rather sophisticated task. The intensity, pulse time sequence and pulse width depend on the mutual orientation of the wind turbine and radio telescope antenna, receiving equipment and conditions of observations, speed of wind turbine rotation, activity of the transmitter reflected from the wind turbine blade and a lot of other circumstances.

The analysis of possible interference from wind turbines for different radio telescopes involves mostly the evaluation of pulse interference intensity produced by the reflection or scattering of some known or hypotetical transmitter emission and its comparison with the interference threshold limit that could fully disturb the radio astronomical observation [1], [2]. Usually the effective path loss from the transmitter to the radio telescope is obtained taking into account the emission scattering on the wind turbine blade and far side lobes of the antenna pattern diagram [4], [5].

The same evaluation of pulse interference intensities and their appearance probabilities were performed for VIRAC radio telescopes RT-32 and RT16. In this evaluation, hypotetical transmitters of $1 \mathrm{KW}$ power and $100 \mathrm{MHz}$ band width (similar GSM basic station transmitters) located in Ventspils, Jaunupe, Miķeḷtornis, Jaunpope, Dundaga are considered. 
The interference emission is assumed to be reflected or diffracted from one blade of wind turbines located in Platene and Vede. The radio telescope RT-32 antenna pattern diagram for far side lobes was assumed in recommendation [7] (Fig. 5 , a). The spatial passive pattern diagram for the wind turbine blade was assumed similar to the one described in [4]. The diagram consists of the direct reflection from the elliptical cylinder surface and diffraction diagram on the blade edge where the blade is illuminated normally to its surface (Fig. 5, b).
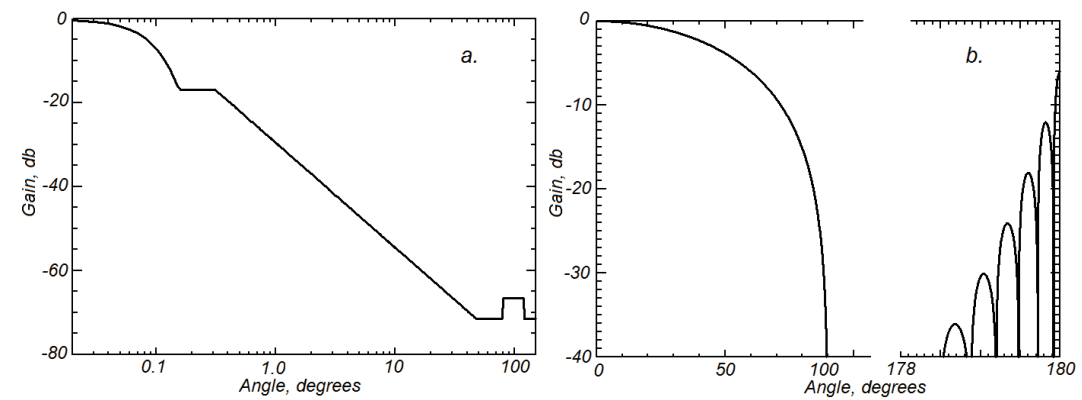

Fig. 5. RT-32 antenna pattern diagram of far side lobes assumed in recommendation [8] (a) and the passive blade reflection and diffraction pattern diagram at $6 \mathrm{~cm}$ wavelength (b).

Obviously, the maximal intensity of the pulse interference ("the worst case") can be observed when the radio telescope is directed to the wind turbine (the observational azimuth of RT-32 is $212 \mathrm{deg}$. to Platene and $188 \mathrm{deg}$. to Vede) and the antenna elevation is lowest ( $8 \mathrm{deg}$. for RT-32). On the other hand, the wind turbine has to be directed to get some maximal reflection of the external transmitter for "the worst case". As a result, calculations under the above-mentioned conditions of spectral flux densities of pulse interference produced by one blade of the wind turbine from some transmitters are shown in Table 1. Spectral flux densities of pulse interference are calculated in Jansky $\left(1 \mathrm{Ja}=10^{-26} \mathrm{Wm}^{-2} \mathrm{~Hz}^{-1}\right)$ for comfortable comparison with real radio astronomical observation data.

According to recommendation [7], the threshold spectral flux density of interference for C-band VLBI observations does not exceed 100 Ja. Spectral flux densities of radio astronomical sources observed during VLBI session are mostly about 5-50 Ja. Taking into account that the system temperature of new cryogenic receiver is about $20 \mathrm{~K}$, the spectral flux density of some external emission in C-band corresponding to this value is about $30 \mathrm{Ja}$. Thus, it is evident that in the "worst case" intensities of pulse interference affected by RT-32 do not exceed the threshold level but can exceed intensities of most radio sources in C-band and the system noise of the receiver.

Obviously, the "worst case" of observations is very rare and real intensities of pulse interference should be lower or absent in most cases. The appearance probability of interference related to the "worst case" is shown in Fig. 6. Obtaining the probability of pulse interference appearance, the omnidirectional orientation of wind turbines and prior radio astronomical observations in the southern hemisphere in the range of elevations of about 8-80 degrees was considered. One can evaluate that the 
"worst case" is almost impossible, but interference with 10 percent of "worst case" intensity could appear at every fifth observation.

The Spectral Flux Density of Maximal Pulse Interference ("worst case")

Produced by the Reflection and Scattering of 1 KW Transmitter Emission from the One Blade of a Wind Turbine and Applied to Radio Telescope RT-32 Input

\begin{tabular}{|l|c|c|}
\hline Source & Reflection from Platene & Reflection from Vede \\
\hline Ventspils & $6.9 \mathrm{Ja}$ & $5.9 \mathrm{Ja}$ \\
\hline Jaunupe & $8.3 \mathrm{Ja}$ & $5.5 \mathrm{Ja}$ \\
\hline Mikeltornis & $2.2 \mathrm{Ja}$ & $39.6 \mathrm{Ja}$ \\
\hline Jaunpope & $14.1 \mathrm{Ja}$ & $10.4 \mathrm{Ja}$ \\
\hline Dundaga & $0.9 \mathrm{Ja}$ & $6.5 \mathrm{Ja}$ \\
\hline
\end{tabular}

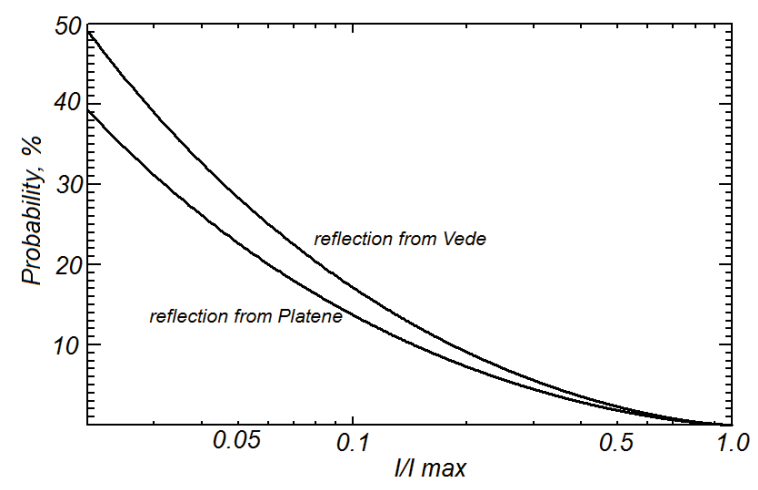

Fig. 6. The dependence of pulse interference probability appearance on the interference intensity related to maximal intensity ("worst case").

Summarising all these issues and taking into account the number of transmitters and wind turbines acting simultaneously, one can conclude that pulse interference produced by wind turbines of wind park "Platene" can actually disturb radio astronomical observations in Irbene.

\section{CONCLUSIONS}

Even some preliminary and rough analyses and evaluations of intensities of pulse electromagnetic interference produced by towers and moving blades of wind turbines have shown that wind park "Platene" in some cases is able fully to disturb radio astronomical observations performed by VIRAC radio telescopes RT-32 and RT-16. Almost in all other cases the influence of the wind park on observations is still noticeable.

More precise analysis of circumstances of the pulse interference emergence and propagation in the area of Irbene is necessary. The permanent monitoring of electromagnetic interference and determination of its sources must be a mandatory part of the observational activity. Methods of the precise detection of pulse interference appearance and its mitigation have to be developed. 
The present research has been performed in the framework of ESF project "Assessment of Wind Energy Potential in Latvia and Environmental Impact from Wind Energy Installations”, 2014/0010/1DP/1.1.1.2.0/13/APIA/VIAA/033.

\section{REFERENCES}

1. Jessner, A. (2011). Report on Windfarms and Radio Astronomy. Available at http://www. craf.eu/CRAF-11-01.pdf .

2. Jessner, A. (2010). Wind Power and Radio Astronomy. Available at http://www.craf.eu/ windturb/Wind\%20Power\%20and\%20Radio\%20Astronomy.ppt.

3. Mattsson, S. (2010). Windturbines vs Radiosystems. Available at http://www.craf.eu/ windturb/Vindkraft_Chalmers-Onsala_100427.ppt.

4. Bendz, E. (2010). Electromagnetic Interference from Wind Turbines on Onsala Space Observatory. Available at http://www.craf.eu/windturb/Electromagnetic\%20Interference $\% 20$ from $\% 20$ Wind $\% 20$ Turbines $\% 20$ on $\% 20$ Onsala $\% 20$ Space_1.pptx .

5. Bolli, P. (2010). Measurements of Primary Radiation at a Wind Farm Close to the Sardinia Radio Telescope. Available at http://www.craf.eu/windturb/Bolli.ppt.

6. Grypstra, K. (2010). Secondary RF-Emissions from Wind Energy Parks, http://www. craf.eu/windturb/Secondary\%20RF-Emissions \%20from $\% 20$ Wind $\% 20$ Energy $\% 20$ Parks\%20100427.ppt.

7. Recommendation ITU-R RA.769-2. (2003). Protection Criteria Used for Radio Astronomical Measurement. Available at http://www.itu.int/rec/R-REC-RA.769-2-200305-I .

8. Recommendation ITU-R SA.509-1. (2013). Space Research Earth Station and Radio Astronomy Reference Antenna Radiation Pattern for Use in Interference Calculations. Available at https://www.itu.int/rec/R-REC-SA.509-3-201312-I/en.

\section{VĒJA ĢENERATORU IETEKME UZ RADIOASTRONOMISKIEM NOVERROJUMIEM IRBENE}

\section{Bezrukovs}

Kopsavilkums

Komunikācijas un navigācijas iekāru raidītāju starojums, atstarojoties vai difragèejot no vēja ǵeneratora, kas novietots noteiktā augstumā virs Zemes, un no vēja turbīnas kustībā esošām lāpstiņām, rada īsus papildus elektromagnētiskos traucējumus, kas nopietni var ietekmēt radioastronomiskos novērojumus. Pašlaik tāda problēma ir Ventspils Starptautiskā Radioastromonijas Centra (VIRAC) radioteleskopiem, jo vēja parks "Platene" atrodas radioteleskopu antenas tuvajā zonā. Rakstā veikti šādu īsu impulsu traucējumu intensitātes un to parādīšanās varbūtības novērtējumi un to ietekme uz radioastronomiskiem novērojumiem ar VIRAC radio teleskopu RT-16 un RT-32

16.09.2015. 